\title{
Morphology of the Spleen in the European Bison and Its Hybrids with Domestic Cattle
}

\author{
Stanisław PYTEL, Małgorzata KRASIŃSKA \& Mieczysław WĘGRZYN
}

\begin{abstract}
Pytel S., Krasińska M. \& Węgrzyn M., 1977: Morphology of the spleen in European bison and its hybrids with domestic cattle. Acta theriol., 22. 7: $141-149$ [With 4 Tables \& 3 Figs.].

Morphological observations were made and linear measurements and weight taken on material consisting of 42 European bisons, ranging in age from 1 day to 24 years, and 32 hybrids between the European bison and cattle, belonging to different generations and aging 5 months 9 years. The spleen of the European bison is heavier than of domestic cattle and in adult specimens it reaches $1712.5 \mathrm{~g}$ or $0.26 \%$ of live weight (males) and $1505.0 \mathrm{~g}$ or $0.29 \%$ of live weight (females); it is also longer and broader (respectively, 64.53 and $63.73 \mathrm{~cm}$ long and 21.04 and $21.77 \mathrm{~cm}$ broad) than in cattle. The spleen of adult $\mathrm{F}_{1}$ hybrids shows some heterotic characters (weight and most measurements) in relation to both the European bison and cattle. In $F_{1}$ females and in backcross hybrids of both sexes the weight of spleen is lower than in the European bison but higher than in cattle.

[Inst. Anim. Physiol., Agric. Acad., 03-849 Warszawa, Grochowska 272 (SP, MW), and Mammals Res. Inst., Polish Acad. Sci., 17-230 Bialowieża (MK)].
\end{abstract}

\section{INTRODUCTION}

The relatively rich literature on the anatomy of the European bison contains only very scanty data concerning the spleen. For instance, M üller (1852) puts off the problem of this organ in the European bison with one sentence: "Die Milz ist im Verhältniss grösser, dunkelroth von Farbe". D i r s ch l m a y e r (1936) ${ }^{1}$ discusses the spleen of ruminants (including the European bison) in its anatomical-histological aspect. A description of the microscopic structure of the spleen of a 10-year-old male European bison is given in a paper by $\mathrm{Z} \mathrm{a} \mathrm{rzy} \mathrm{cki} \mathrm{(1957).}$

In the present study the spleen of the European bison and its hybrids with domestic cattle was submitted to a morphological analysis.

1 The authors failed to get at the original paper, which is known to them only from its summary. 


\section{MATERIAL AND METHODS}

Material consisted of the spleens of 42 European bisons ( 29 males and 13 females) and 32 hybrids, of which 17 were males and 15 females. The age of the European bisons ranged from full-term foetus to 24 years. They were divided into 4 groups: newborns, calves, juveniles and adults (Table 1). The hybrids, whose detailed characterization is given in a paper by $\mathrm{Krasinska} \mathrm{\&} \mathrm{Pilarski} \mathrm{(1977),}$ were divided, after those authors, into groups according to generation, age and sex (Table 2).

The spleens of European bisons were obtained from dead animals or those put to sleep for different reasons and under different circumstances. The hybrids were slaughtered in the manner and conditions described by Sz u lc et al., (1971).

Observations were carried out both on fresh material (all hybrids and 22 European bisons) and fixed material (20 European bisons) by the method of intra-arterial injections ( $\mathrm{Pilarski}$ et al., 1967) or by immersion in a $3-4 \%$ aqueous solution of formalin.

The spleen was weighed to an accuracy of $1 \mathrm{~g}$ and measured by means of a slide-caliper and measuring tape to an accuracy of $0.1 \mathrm{~cm}$. Measurements were based on the authors' own scheme (Fig. 1).

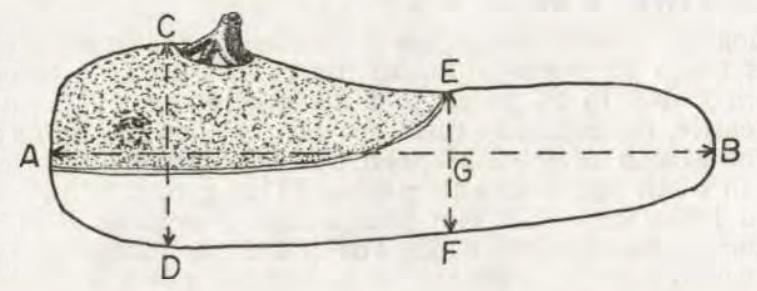

Fig. 1. A diagram showing the measuring points of the spleen exemplified by an unfixed specimen seen from the visceral side; the non-peritoneal area is dotted. A-B - overall length, C-D - width at dorsal extremity, G-B - length of the socalled free (detached) part, E-F - width at ventral extremity; the thickness of the organ was measured at the point of crossing of the lines $A-B$ and $C-D$.

Observations on the position of the spleen were made on 8 European bisons fixed in toto. They were confronted with the situation found in three domestic cows fixed in the same way for other purposes.

\section{RESULTS}

\subsection{Spleen of European Bison}

\subsubsection{Shape and Position}

The unfixed spleen of the European bison is in the shape of an elongate oval, the longer side of which measures on the average $64.3 \mathrm{~cm}$ and the shorter side $21.3 \mathrm{~cm}$ in adult specimens, the differences between males and females not exceeding $1 \mathrm{~cm}$ (Table 1). However, it is not a perfectly regular oval, since the dorsal pole of the spleen in $0.8-4.84 \mathrm{~cm}$ wider than its ventral pole in European bisons of various 
age groups. The fixed spleen in its natural position is twisted so that the lower part of the organ is directed laterally to the body axis and the dorsal part anterosuperiorly. The dorsal pole of the spleen of the European bison is shaped like a helmet $4-13 \mathrm{~cm}$ deep (Fig. 2A). The caudal margin is as a rule sharp (this is also sometimes true of the margin of the dorsal pole), whereas the remaining margins are generally rounded. In the places of adhesion with the wall of the rumen and the

Table 1

Average spleen measurements $( \pm S D)$ of European bison (weights in $\mathrm{g}$, linear measurements - in $\mathrm{cm}$ ).

\begin{tabular}{|c|c|c|c|c|c|c|c|c|}
\hline Group/age & $\mathrm{n}$ & $\begin{array}{c}\text { Absolute } \\
\text { weight }\end{array}$ & $\begin{array}{l}\text { Relative } \\
\text { weight }\end{array}$ & $\begin{array}{l}\text { Length } \\
\mathrm{A}-\mathrm{B}\end{array}$ & $\begin{array}{c}\text { Breadth } \\
\text { C - D }\end{array}$ & $\begin{array}{l}\text { Breadth } \\
\mathrm{E}-\mathrm{F}\end{array}$ & $\begin{array}{l}\text { Length } \\
\mathrm{G}-\mathrm{B}\end{array}$ & $\begin{array}{c}\text { Thick- } \\
\text { ness }\end{array}$ \\
\hline \multicolumn{9}{|c|}{ Without conservation } \\
\hline Newborn & 5 & $\begin{array}{r}44.00 \\
\pm 9.42 \\
n=3\end{array}$ & $\begin{array}{l}0.18 \\
\mathrm{n}=2\end{array}$ & $\begin{array}{r}16.12 \\
\pm 1.58\end{array}$ & $\begin{array}{r}5.50 \\
\pm 0.51\end{array}$ & $\begin{array}{r}4.44 \\
\pm 0.30\end{array}$ & $\begin{array}{r}6.28 \\
\pm 0.51\end{array}$ & $\begin{array}{r}0.92 \\
\pm 0.18\end{array}$ \\
\hline $\begin{array}{l}\text { Calf } \\
1.5-4 \\
\text { months }\end{array}$ & 3 & $\begin{array}{l}230.00 \\
\mathrm{n}=2\end{array}$ & $\begin{array}{r}0.39 \\
\mathrm{n}=1\end{array}$ & $\begin{array}{r}32.50 \\
\pm 1.42\end{array}$ & $\begin{array}{r}11.83 \\
\pm 1.64\end{array}$ & $\begin{aligned} & 11.03 \\
\pm & 0.85\end{aligned}$ & $\begin{array}{r}8.80 \\
\pm 0.51\end{array}$ & $\begin{array}{r}1.65 \\
\mathrm{n}=2\end{array}$ \\
\hline $\begin{array}{l}\text { Young } \\
2-3.5 \text { yrs }\end{array}$ & 2 & $\begin{array}{r}1150.00 \\
n=1\end{array}$ & $\begin{array}{l}0.28 \\
\mathrm{n}=1\end{array}$ & 46.00 & 17.00 & 12.75 & 18.25 & 3.10 \\
\hline Adult M & 8 & 1712.50 & 0.26 & $\begin{array}{r}64.53 \\
+5.11\end{array}$ & $\begin{array}{r}21.04 \\
+0.55\end{array}$ & 16.56 & 21.50 & $\begin{array}{r}3.04 \\
+0.49\end{array}$ \\
\hline $\begin{array}{l}6-17 \text { yrs } \\
\text { Adult } F\end{array}$ & 4 & $\begin{array}{c} \pm 646 \\
1505.00\end{array}$ & $\begin{array}{c}\mathrm{n}=6 \\
0.29\end{array}$ & $\begin{array}{r} \pm 5.11 \\
63.73\end{array}$ & $\begin{array}{r} \pm 2.55 \\
21.77\end{array}$ & $\begin{array}{r} \pm 2.71 \\
16.93\end{array}$ & $\begin{array}{r} \pm 2.55 \\
22.40\end{array}$ & $\begin{array}{r} \pm 0.49 \\
3.20\end{array}$ \\
\hline $8-18$ yrs & & $\begin{array}{r} \pm 465 \\
n=3\end{array}$ & $\mathrm{n}=2$ & \pm 6.00 & \pm 1.63 & \pm 0.89 & \pm 5.83 & \pm 0.78 \\
\hline $\begin{array}{l}\text { Adult } \mathrm{M}+\mathrm{F} \\
6-18 \mathrm{yrs}\end{array}$ & 12 & $\begin{array}{r}1655.91 \\
\pm 425 \\
n=11\end{array}$ & $\begin{array}{l}0.27 \\
n=8\end{array}$ & $\begin{array}{r}64.27 \\
\pm 5.36\end{array}$ & $\begin{array}{r}21.31 \\
\pm 2.32\end{array}$ & $\begin{array}{r}16.70 \\
\pm 2.15\end{array}$ & $\begin{array}{l}21.95 \\
\pm 4.40\end{array}$ & $\begin{array}{r}3.10 \\
+0.67\end{array}$ \\
\hline \multicolumn{9}{|c|}{ After conservation } \\
\hline Newborn & 4 & $\begin{array}{r}51.05 \\
\pm 26.61\end{array}$ & 0.23 & $\begin{array}{r}14.65 \\
\pm 2.23\end{array}$ & $\begin{array}{r}5.78 \\
\pm 0.77\end{array}$ & $\begin{array}{r}4.52 \\
\pm 0.81\end{array}$ & $\begin{array}{r}4.33 \\
\pm 0.33\end{array}$ & $\begin{array}{l}1.10 \\
\mathrm{n}=2\end{array}$ \\
\hline $\begin{array}{l}\text { Young } \\
1-2 \text { yrs }\end{array}$ & 3 & - & - & $\begin{array}{r}47.83 \\
\pm 2.59\end{array}$ & $\begin{array}{r}15.77 \\
\pm 2.55\end{array}$ & $\begin{array}{r}12.50 \\
\pm 1.87\end{array}$ & $\begin{array}{c}13.45 \\
n=2\end{array}$ & $\begin{array}{r}3.33 \\
\pm 0.91\end{array}$ \\
\hline $\begin{array}{l}\text { Adult M } \\
4-17 \text { yrs } \\
\text { years }\end{array}$ & 9 & $\begin{array}{r}6328.00 \\
\pm 848 \\
n=5\end{array}$ & $\begin{array}{c}0.92 \\
n=2\end{array}$ & $\begin{array}{r}64.34 \\
\pm 13.02\end{array}$ & $\begin{array}{r}25.79 \\
\pm 9.09\end{array}$ & $\begin{array}{r}18.03 \\
\pm 5.32\end{array}$ & $\begin{array}{r}23.49 \\
\pm 10.91\end{array}$ & $\begin{array}{r}5.36 \\
\pm 1.48\end{array}$ \\
\hline Adult $\mathrm{F}$ & 4 & - & 一 & 62.00 & 20.50 & 14.22 & 20.75 & 4.12 \\
\hline $16-24$ yrs & & & & \pm 2.16 & \pm 3.24 & \pm 2.89 & $\mathrm{n}=2$ & \pm 1.09 \\
\hline $\begin{array}{l}\text { Adult } \mathrm{M}+\mathrm{F} \\
4-24 \text { yrs }\end{array}$ & 13 & - & - & $\begin{array}{r}63.76 \\
+11.34\end{array}$ & $\begin{array}{r}24.47 \\
\pm 8.35\end{array}$ & $\begin{array}{r}16.86 \\
\pm 5.02\end{array}$ & $\begin{array}{r}22.94 \\
\pm 9.82\end{array}$ & $\begin{array}{r}4.98 \\
\pm 1.48\end{array}$ \\
\hline
\end{tabular}

left pillar of the diaphragm the dorsoposterior part of the visceral surface of the spleen and the upper part of its diaphragmatic surface are devoid of the serous tunic. The splenic pulp, visible through the fibrous tunic, is blue-grey or cherry red-grey in colour, sometimes in a pink shade. The hilum of the spleen is situated on its cranial margin, close to the dorsal pole of the organ.The length of the hilum ranges from 4.5 to $10 \mathrm{~cm}$. 
The spleen of the European bison is whole on the left side of the abdominal cavity, chiefly in the left subcostal region. Its superior portion is squeezed in between the dorsal margin of the anterior end of the rumen and the left pillar of the diaphragm (Fig. 3). The dorsal pole of the spleen lies at the height of the bodies of the last two, 15th

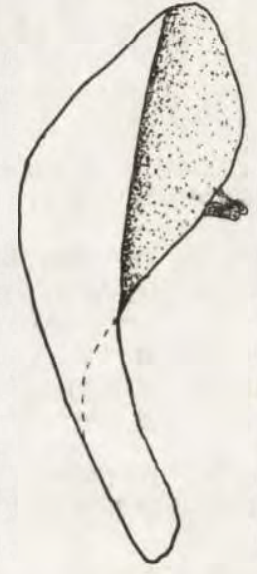

A

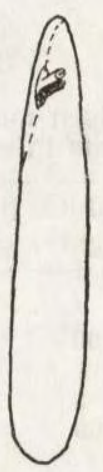

B

Fig. 2. Fixed spleen (retaining its natural shape) seen from the side of the parietal surface and anterior border: A - of the European bison, B - of the domestic cattle.

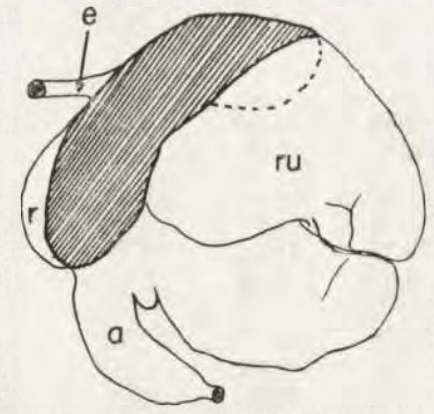

A

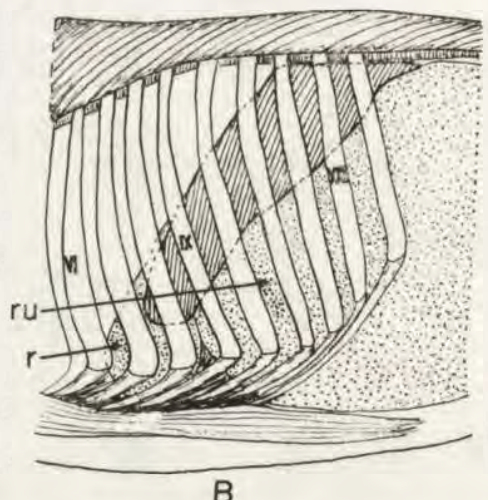

B

Fig. 3. Position of the spleen of the European bison.

A-removed with the rumen, B-in situ; $\mathrm{r}$-reticulum, a-abomasum, rurumen, e-esophagus, VI, IX, XIII - ribs.

and 14th, vertebrae and the first (occasionally the second) lumbar vertebra. The ventral pole of the spleen, unlike the dorsal one, is not usually adhered to the adjacent organs and as a free structure may lie in the fossa for the rumen and reticulum, opposite the sternal ends of 
the 7 th and 8 th ribs, or it may be displaced backwards behind the costal arch. as far as the extension of the 9 th and 10th ribs. In dependence upon the length of the spleen its ventral pole lies 8 to $25 \mathrm{~cm}$ above the cartilage of the xiphoid process of the sternum.

\subsubsection{Changes in Spleen Size with Age}

In the postnatal development the spleen of European bisons keeps its more or less constant oval shape, defined within little changing limits, for the length: wildth ratio of the spleen is on the average 2.9 (in new-

Table 2

Comparison of average spleen measurements $( \pm \mathrm{SD})$ of hybrids $F_{1}, B_{1}, B_{2}$ (without conservation).

\begin{tabular}{|c|c|c|c|c|c|c|c|c|}
\hline $\begin{array}{l}\text { Group/age, } \\
\text { years }\end{array}$ & $\mathrm{n}$ & $\begin{array}{l}\text { Absolute } \\
\text { weight }\end{array}$ & $\begin{array}{c}\text { Relative } \\
\text { weight }\end{array}$ & $\begin{array}{l}\text { Length } \\
\mathrm{A}-\mathrm{B}\end{array}$ & $\begin{array}{l}\text { Breadth } \\
\text { C }-D\end{array}$ & $\begin{array}{c}\text { Breadth } \\
\mathrm{E}-\mathrm{F}\end{array}$ & $\begin{array}{l}\text { Length } \\
\text { G - B }\end{array}$ & $\begin{array}{l}\text { Thick- } \\
\text { ness }\end{array}$ \\
\hline \multicolumn{9}{|c|}{ MALES } \\
\hline $\begin{array}{l}\text { Hybris } F_{1} \\
5-12.5\end{array}$ & 3 & $\begin{array}{c}2142.0 \\
\pm 495.0 \\
n=5\end{array}$ & $\begin{array}{l}0.28 \\
n=5\end{array}$ & $\begin{array}{r}67.67 \\
+0.98\end{array}$ & 18.5 & $\begin{array}{r}17.50 \\
\pm 1.50\end{array}$ & $\begin{array}{r}25.17 \\
\pm 4.71\end{array}$ & $\begin{aligned} & 3.0 \\
\pm & 0.42\end{aligned}$ \\
\hline $\begin{array}{l}\text { Hybrids } \quad B_{1} \\
3.5-5.5 \\
\text { Hybrids } B_{1} \\
1.5-2.5 \\
\text { Hybrids } \quad B_{1}\end{array}$ & $\begin{array}{l}7 \\
3 \\
2\end{array}$ & $\begin{array}{r}1455.7 \\
\pm 143.0 \\
1230.0 \\
\pm 193.0 \\
975.0\end{array}$ & 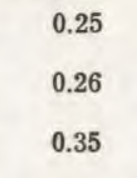 & $\begin{array}{r}59.11 \\
\pm 2.16 \\
56.20 \\
\pm 7.14 \\
45.35\end{array}$ & $\begin{array}{c}15.30 \\
\pm 0.52 \\
13.35 \\
n=2 \\
13.30\end{array}$ & $\begin{array}{r}14.27 \\
\pm 0.85 \\
14.00 \\
\pm 4.20 \\
12.50\end{array}$ & $\begin{array}{r}22.14 \\
\pm 3.78 \\
16.50 \\
\pm 3.89 \\
16.75\end{array}$ & $\begin{array}{r}2.6 \\
\pm 0.5 \\
2.6 \\
+0.0 \\
2.7\end{array}$ \\
\hline \multicolumn{9}{|c|}{ FEMALES } \\
\hline $\begin{array}{l}\text { Hybrids } \mathrm{F}_{1} \\
4-9\end{array}$ & 2 & $\begin{array}{l}1026.7 \\
n=3\end{array}$ & & 62.25 & 15.50 & 13.25 & 21.00 & 2.2 \\
\hline $\begin{array}{l}\text { Hybrids } \mathrm{B}_{1} \\
4.5-7.5\end{array}$ & 5 & $\begin{array}{r}1386.0 \\
\pm 204.0\end{array}$ & 0.26 & $\begin{array}{r}51.60 \\
\pm 4.10\end{array}$ & $\begin{array}{r}13.80 \\
\pm 1.40\end{array}$ & $\begin{array}{r}14.20 \\
\pm 0.89\end{array}$ & $\begin{array}{r}14.60 \\
\pm 2.40\end{array}$ & $\begin{aligned} & 2.6 \\
\pm & 0.45\end{aligned}$ \\
\hline $\begin{array}{l}\text { Hybrids } B_{1} \\
1-2.5\end{array}$ & 3 & $\begin{array}{r}1146.7 \\
\pm 50.9\end{array}$ & 0.38 & $\begin{array}{r}50.60 \\
\pm 0.32\end{array}$ & $\begin{array}{r}15.50 \\
\pm 0.00\end{array}$ & $\begin{array}{r}12.57 \\
\pm 0.55\end{array}$ & $\begin{array}{r}13.33 \\
+5.22\end{array}$ & $\begin{array}{r}2.7 \\
\pm 0.4\end{array}$ \\
\hline $\begin{array}{l}\text { Hybrids } B_{1} \\
0.5\end{array}$ & 1 & 820.0 & 0.35 & 40.00 & 13.00 & 11.00 & 13.00 & 2.3 \\
\hline $\begin{array}{l}\text { Hybrids } \mathrm{B}_{2} \\
2.5-4.5\end{array}$ & 3 & $\begin{array}{r}1250.0 \\
\pm 132.0\end{array}$ & 0.25 & $\begin{array}{r}48.67 \\
\pm 5.40\end{array}$ & $\begin{array}{r}13.93 \\
\pm 0.41\end{array}$ & $\begin{array}{r}13.27 \\
\pm 0.64\end{array}$ & $\begin{array}{r}12.50 \\
\pm 0.41\end{array}$ & $\begin{aligned} & 2.8 \\
\pm & 0.24\end{aligned}$ \\
\hline
\end{tabular}

borns) and 3.0 in grown-up specimens. The proportional increase in particular measurements of the spleen with age is evidenced also by the growth indices, which approximate each other: 4.1 for its length and 3.9 for the width. An analysis of the data presented in the table suggests that calves and juveniles have the highest increments in the absolute weight of spleen. The growth indices, calculated in relation to the preceding age groups, are respectively 5.2 and 5.0, whereas this index is only 1.4 for adult specimens. Throughout the postnatal development of the European bison the absolute weight of spleen increases 34.2 times and reaches $1712.5 \mathrm{~g}$ in adult males and more than $200 \mathrm{~g}$ less in females (Table 1). The spleens of 1.5-4-month-old European bisons are charac- 
terized by the highest relative weight $(0.39 \%$ of live weight), whereas older and adult specimens have the relative weights of spleen lower but approximating each other. They are always higher in females than in males, which should be referred to the smaller body weight of these last.

The length and width of the fixed spleen differ slightly from those obtained with the fresh material, but its thickness is decidedly greater (Table 1). The weight of fixed spleens is many times as high as that of the fresh organs, which is obviously due to the intra-arterial injection technique used.

\subsection{Weight and Measurements of Spleen in Hybrids}

The highest absolute weight of spleen was found in adult $\mathrm{F}_{1}$ males (Table 2). In adult $B_{1}$ males the spleen is $32 \%$ lighter than in $F_{1}$ males

Table 3

Comparison of spleen weights of adult European bison, cattle and their hybrids (in $\mathrm{kg}$ ).

\begin{tabular}{|c|c|c|c|}
\hline Group of animals & Absolute wt. ( $\pm \mathrm{SD})$ & Relative wt. & References \\
\hline \multicolumn{4}{|c|}{ MALES } \\
\hline European bison & $1.712 \pm 0.646$ & $0.26(0.14-0.53)$ & Present study \\
\hline Cattle & $0.878(0.39-1.39)$ & $0.15(0.12-0.19)$ & Schneider (1904) \\
\hline Cattle $^{1}$ & $1.555(0.715-2.0)$ & $0.16(0.12-0.23)$ & Schneider (1904) \\
\hline Hybrids $\mathrm{F}_{1}$ & $2.142 \pm 0.495$ & $0.28(0.19-0.30)$ & Present study \\
\hline Hybrids $\mathrm{B}_{1}$ & $1.456 \pm 0.143$ & $0.25(0.24-0.28)$ & Present study \\
\hline \multicolumn{4}{|c|}{ FEMALES } \\
\hline European bison & $1.505 \pm 0.465$ & $0.29(0.19-0.38)$ & Present study \\
\hline Cattle & $0.789(0.45-1.2)$ & $0.17(0.14-0.22)$ & Schneider (1904) \\
\hline Cattle $^{2}$ & $0.880 \pm 0.22$ & 0.21 & Kwiatkowski (1973) \\
\hline Cattle $^{3}$ & $0.930 \pm 0.22$ & 0.25 & Kwiatkowski (1973) \\
\hline Hybrids $F_{1}$ & $1.026 \pm 0.110$ & $0.20(0.17-0.22)$ & Present study \\
\hline Hybrids $B_{1}$ & $1.386 \pm 0.204$ & $0.26(0.19-0.32)$ & Present study \\
\hline Hybrids $\mathrm{B}_{2}$ & $1.250 \pm 0.132$ & $0.25(0.23-0.28)$ & Present study \\
\hline
\end{tabular}

1 Ox; $2^{2}$ Polish red; 3 Jersey

and in adult $\mathrm{B}_{1}$ females it is heavier by above $300 \mathrm{~g}(35 \%)$ than in $\mathrm{F}_{1}$ females.

The relative weight of spleen is higher in adult $F_{1}$ males than in the corresponding $B_{1}$ males, while in females a reversed situation is observed. In the $\mathrm{B}_{1}$ generation, for only in this group specimens differing in age were availabie, a fall with age was found in the relative weight of spleen, regular in males and less regular in females (Table 2).

Both the length of the spleen and the width at its dorsal pole (measurement $C-D$ ) have their highest mean values in $F_{1}$ hybrids and they are somewhat smaller in females than in males (Table 2). The length: width ratio of spleen in hylbrids is the average 3.6 and changes with age and 
from generation to generation, ranging 3.1 in a half-a-year-old $\mathrm{B}_{1}$ heifer to 4.2 in the group of $1.5-2.5$-year-old $\mathrm{B}_{1}$ males.

\section{DISCUSSION}

The spleen of the European bison has a similar position to that of the spleen in domestic cattle ( $\mathrm{Nickel}$ et al., 1975), but being wider at the dorsal pole it extends farther to the back. This should be also regarded as responsible for the formation of the deep through-shaped dorsal portion of the spleen characteristic of the European bison. Only a concavity in the visceral surface of the spleen has been described in the case of cattle (St e g e r, 1939).

The mean weight of the spleen of male European bisons is higher than that of the males of cattle and $\mathrm{B}_{1}$ hytbrids, but at the same time lower than in $F_{1}$ hybrids (Table 3 ). As regards the absolute weight of spleen the $F_{1}$ hybrids also come in first and are followed by European bisons,

Table 4

Comparison of average spleen measurements of adult European bison (taken as 100 per cent) and their hybrids.

\begin{tabular}{|c|c|c|c|c|c|}
\hline Group of animals & $\begin{array}{l}\text { Length } \\
\mathrm{A}-\mathrm{B}\end{array}$ & $\begin{array}{c}\text { Breadth } \\
C-D\end{array}$ & $\begin{array}{l}\text { Breadth } \\
E-F\end{array}$ & $\begin{array}{l}\text { Length } \\
\mathrm{G}-\mathrm{B}\end{array}$ & Thickness \\
\hline \multicolumn{6}{|c|}{ MALES } \\
\hline European bison & 100 & 100 & 100 & 100 & 100 \\
\hline Hybrids $F_{1}$ & 105 & 88 & 106 & 117 & 99 \\
\hline Hybrids $B_{1}$ & 92 & 73 & 86 & 103 & 86 \\
\hline \multicolumn{6}{|c|}{ FEMALES } \\
\hline European bison & 100 & 100 & 100 & 100 & 100 \\
\hline Hybrids $F_{1}$ & 98 & 71 & 78 & 94 & 69 \\
\hline Hybrids $B_{1}$ & 81 & 63 & 84 & 65 & 81 \\
\hline Hybrids $\mathrm{B}_{2}$ & 76 & 60 & 79 & 56 & 88 \\
\hline
\end{tabular}

$\mathrm{B}_{1}$ hybrids and, finally, bulls and oxen, these last two groups yielding decidedly to the remaining animals. These facts confirm the phenomenon of hetorosis, observed earlier in the alimentary canal, liver, heart and kidneys (Pytel \& Krasińska, 1971; Krasińska \& Pilarski, 1977 ) in the intergeneric hybrids between the European bison and domestic cattle.

The spleen of females is heavier in European bisons than in cattle and hybrids; the smallest differences occur in $\mathrm{B}_{1}$ hybrids, the greatest in domestic cattle in comparison with the data given by S c h n e id e r (1904).

The spleen of the European bison attains higher values for all measurements than it does in cattle, female hybrids of all generations and $\mathrm{B}_{1}$ males. Only in males of the $F_{1}$ generation it is longer and less broadened at the dorsal pole than in the European bison (Table 4). 
The lack of distinct heterotic features in the measurements and weight of the spleen of female hybrids may be due to their small number (2 specimens of the $F_{1}$ generation), even though, as has already been fcund ( $\mathrm{Kr}$ a s ins $\mathrm{k}$ a, 1969), in females the characters are not as luxuriant as in male hybrids between the European bison and domestic cattle.

\section{REFERENCES}

1. Dirschlmayer K., 1936: Beitrag zur vergleichende Anatomie und Hstologie der Milz bei den Wiederkaüern. Wien. Tierärztl. Mschr., 23: 648 .

2. Krasińska M., 1969: The postnatal development of $F_{1}$ hybrids of the European bison and domestic cattle. Acta theriol., 14, 7: 69-117.

3. Krasińska M. \& Pilarski W., 1977: Biometric analysis of some internal organs of hybrids between the European bison and domestic cattle. Acta theriol. 22, 6: 121-139.

4. Kwi a tk owski J., 1973: Próba oceny i porównania wartości rzeźnej krów rasy polskiej czerwonej, jersey i mieszańców $F_{1}$ tych ras. Pr. Mater. Zoot, 3: $7-22$.

5. Mülle r F., 1852: Bemerkungen über den Aurochsen. Vierteljahrschr. Wiss. Veterinärkde, 2: 110-133. Berlin.

6. Nickel R., Schummer A. \& Seiferle E., 1975: Lehrbuch der Anatomie der Haustiere. Parey, 2: 201-206. Berlin, Hamburg.

7. Pilarski W., Serwatka S., Swieżyński K. \& Węgrzyn M., 967: New attemps at fixing anatomical material of large mammals. Acta theriol, 12, 31: $453-458$.

8. Pytel S. \& Krasińska M., 1971: Morphology of stomach and intestines in hybrids of European bison and domestic cattle. Acta theriol., 16, 31: 471-481.

9. Pytel S. \& Węgrzyn M., 1976: Morphology of the liver in European bison. Acta theriol., 21, 2: 19-30.

10. Schneider J., 1904: Das absolute und relative Gewicht des Herzens, der Lunge, der Leber, der Niere und der Milz. Zeitschr., für Fleisch- u. Milchlyg., 16: $393-398$.

11. Schulz P., 1956: Masse und Gewichte der Milzen unserer Schlachttiere. Disch. Schlacht.- u. Viehhof. Ztg., 56: 86-88. Herford.

12. St e ger G., 1939: Die tierartlichen Merkmale der Haussaugermilzen bezüglich Form, Hilus und Gefässen. Dtsch. Tierärztl. Wschr., 47: 325-327.

13. Szulc M., Tropiło J. \& Krasińska M., 1971: Dressing percentage and utility value of the meat of European bison and domestic cattle hybrids. Lcta theriol., 16, 32: 483-504.

14. Z a rzycki J., 1957: O budowie histologicznej niektórych narządów wewnętrznych żubra, Bison bonasus L. Zool. Pol., 8: 53-62.

Accepted, May 28, 1976. 
Stanisław PYTEL, Małgorzata KRASIŃSKA i Mieczysław WĘGRZYN

MORFOLOGIA SLEDZIONY ŻUBRA I MIESZANCOW Z BYDEEM DOMOWYM

\section{Streszczenie}

Obserwacje morfologiczne oraz pomiary liniowe i wagowe wykonano na materiale obejmującym sledziony 42 żubrów $(29,13) \mathrm{w}$ wieku od 1 dnia do 24 lat (Tabela 1) a także 32 mieszańców z bydłem domowym $(17,15)$ w wieku od 5 miesięcy do 9 lat (Tabela 2).

Sledziona żubra ma kształt podłużnego owalu o rozszerzonym końcu grzbietowym nakładającym się jak hełm na przednią część krzywizny grzbietowej żwacza (Ryc. 2) na wysokości 13-14 kręgu piersiowego i pierwszego kręgu lędźwiowego (Ryc. 3). Sledziona u żubra jest cięższa niż u bydła domowego i osiąga u sztuk dorosłych $1712.5 \pm 646 \mathrm{~g}$ i $0.26 \%$ (samce) oraz $1505.0 \pm 465 \mathrm{~g} \mathrm{i} 0.29 \%$ (samice); jest ona także dłuższa (odpowiednio $64.53 \pm 5.11 \mathrm{~cm} \mathrm{i} 63.73 \pm 6.00 \mathrm{~cm}$ ) i szersza $21.04 \pm 2.55$ i $21.77 \pm 1.63 \mathrm{~cm}$ ). Sledziona dorosłych mieszańców pierwszego pokolenia wykazuje wybujałość cech (ciężar i większość pomiarów) ale tylko wśród samców; w pierwszym pokoleniu samic, jak również u krzyżówek wstcznych $\left(B_{1}\right.$ i $\left.B_{2}\right)$ obserwuje się niższe wyniki niż u żubrów odpowiedniej płci ale $w$ dalszym ciągu wyższe niż u bydła domowego (Tabela 3,4$)$. 